\title{
Efficiency Analysis of Granted Agricultural Projects
}

\author{
Gulay Ozkan ${ }^{1 *}$, Ismail Bulent Gurbuz ${ }^{2}$, Nezih Erdem Bedel ${ }^{3}$ \\ 1* Bursa Uludag University, Faculty of Agriculture, Department of Agricultural Economics, Bursa, Turkey, \\ (ORCID: 0000-0001-6878-1673), gulayozkan@uludag.edu.tr \\ 2 Bursa Uludag University, Faculty of Agriculture, Department of Agricultural Economics, Bursa, Turkey, \\ (ORCID: 0000-0001-5340-3725), bulent@uludag.edu.tr \\ ${ }^{3}$ Bursa Uludag University, Faculty of Agriculture, Department of Agricultural Economics, Bursa, Turkey, \\ (ORCID: 0000-0002-3546-5794 ), 501813003@ogr.uludag.edu.tr
}

(First received 15 October 2021 and in final form 2 December 2021)

(DOI: 10.31590/ejosat.1010172)

ATIF/REFERENCE: Ozkan, G., Gurbuz, I. B. \& Bedel, N. E. (2021). Efficiency Analysis of Granted Agricultural Projects. European Journal of Science and Technology, (31), 505-514.

\begin{abstract}
IPARD (Instrument for Pre-Accession Assistance Rural Development) Programme supports small and medium-sized enterprises to achieve long-term economic sustainability, ensure stringent quality control, assist the sector's adaptation, and compete in the domestic market. This research aimed to unveil the distinct characteristics of the managers and enterprises of agricultural producers who have received support from the Program. Thus, the effectiveness of the Program in Bursa was questioned. Ninety-seven enterprises that received support from IPARD I and IPARD II were interviewed. Data analysis was performed using the SPSS 25 Program. The vast majority of applicants were men $(78.4 \%)$. Although nearly half of the applicants $(43.3 \%)$ were university graduates, the education of $83.5 \%$ was not related to the sector applied. $76.3 \%$ of them had not received any relevant training or course, and $40.2 \%$ had $1-5$ years of experience in the profession. $84.5 \%$ of IPARD applications were new companies. Applications were evenly distributed between natural and legal entities. Of the investors applying, $59.8 \%$ had no non-agricultural income. ARDSI (58.8\%) and past investors' feedback (30.9\%) effectively informed potential applicants. Meat and milk-producing enterprises benefited the most from the Program; milk processing enterprises benefited the least. $72.2 \%$ of the projects were large-capacity enterprises, and $92.8 \%$ had not increased capacity. The monthly agricultural net income of $32 \%$ of the enterprises receiving support was $20001 \mathrm{TL}$ and above. The company's plans included maintaining its current status $(25.7 \%)$ and investing in additional machinery and equipment without increasing capacity (25.7\%). 89.7\% of the participants follow rural development activities.
\end{abstract}

Keywords: Agriculture and Rural Development, Grant, Agricultural Entity, IPARD, Quality, Sustainability.

\section{Hibe Kapsamında Verilen Tarımsal Projelerin Etkinlik Analizi}

$\ddot{O} z$

IPARD (Katılım Öncesi Yardım Aracı Kırsal Kalkınma) programı küçük ve orta ölçekli işletmelere, uzun dönemde ekonomik sürdürülebilirliği sağlamaları, tüm üretim aşamalarında sıkı bir kalite ve hijyen denetimi uygulamaları ve bu sayede sektöründeki adaptasyonuna katkıda bulunmak ve iç pazarda daha kolay rekabet etmelerini sağlamak için destek olmaktadır. Bu araştırmada Programdan destek almış olan tarımsal üreticilerin programa başvuran yöneticileri ve işletmelerin demografik özellikleri ile birlikte işletme ve sektör ile ilgili bilgiler araştırılarak Programın Bursa İlindeki etkinlik derecesi değerlendirilmiştir. Araştırmada IPARD I ve IPARD II kapsamında destek alan 97 adet işletme ile görüşülmüştür. Veri analizi SPSS 25 Programı aracıllğı ile gerçekleştirilmiştir. Başvuru sahiplerinin büyük çoğunluğunun erkektir (\%78.4). Başvurusu sahiplerinin yaklaşık yarısı (\%43.3) üniversite mezunu olmakla birlikte \%83.5'nin eğitimi proje için başvurulan sektörle ilgili değildir. \%76.3'ü ise ilgili herhangi bir eğitim veya kurs almamıştır ve $\% 40.2$ 'simin meslekteki tecrübeleri 1-5 yıl arasındadır. IPARD başvurularının \% 84.5'ü yeni şirketlerdir. Başvurular gerçek ve tüzel kişiler arasında dengeli bir şekilde dağılmıştır. Başvuru yapan yatırımcıların \%59.8'inin tarım dışı geliri yoktur. Hibe destekleri hakkında ilgilendirmede TKDK (\%58.8) ve hibe desteği almış yatırımcıların bilgilendirmesi (\%30.9) etkili olmuştur. Programdan en çok et ve süt üreten işletmeler en az ise süt işleyen işletmeler faydalanmışıır. Projelerin \% 72.2 'si büyük kapasiteli işletmeler olup \%92.8'i kapasite artırımına gitmemiştir. Destek alan işletmelerin \% 32'sinin aylık tarımsal net geliri $20001 \mathrm{TL}$ ve üstündedir. İşletmenin gelecekle ilgili planları arasında öncelikli olarak mevcut durumunu koruyarak faaliyetlerini sürdürmek (\%25.7) ve kapasite artırımı yapmadan ilave makine ekipman yatırımı yapmak (\%25.7) bulunmaktadır. Katılımcıların \% 89.7'si kırsal kalkınma faaliyetlerini takip etmektedir.

Anahtar Kelimeler: Tarım ve Kırsal Kalkınma, Hibe, Tarımsal İşletme, IPARD, Kalite, Sürdürülebilirlik.

*Corresponding Author: gulayozkan@uludag.edu.tr 


\section{Introduction}

Starting with the Turkey - European Community (EC) Association Agreement signed in 1963, Turkey's relations with the European Union (EU) financial aid have continued for more than fifty years. After gaining the nomination status, there was an increase in Turkey's amount and scope of financial assistance. These benefits provided in many different areas were collected under a single heading by the Council Regulation on preaccession financial aid for Turkey No. 2500/2001 of 17 December 2001. The EU has made significant changes to the budget for 2007-2013. Financial assistance previously allocated from various programs for the candidate and potential candidate countries has been collected under one roof, under the Instrument for Pre-accession Assistance (IPA) name.

The IPARD (Instrument for Pre-accession Assistance Rural Development) program, the fifth component of IPA, plans to implement the acquis on the EU Common Agricultural Policy and the sustainable management of the agricultural sector and rural areas in the candidate countries to comply with the EU acquis. The IPARD program supports the enterprises engaged in primary agricultural production and processing of these agricultural products. It aims to help such enterprises to reach Community standards on the issues of productivity, quality, quality management, hygiene and food safety, animal welfare, veterinary controls, environmental protection (water use, fertilizer and nitrate pollution management) and occupational safety. The IPARD Program supports small and medium-sized enterprises to overcome the economic sustainability threshold in the long term. The Programme implements strict quality and hygiene control in all processing stages, thus contributing to their adaptation in the sector and enabling them to compete more effectively in the domestic market.

Success in achieving the goals set by the IPARD Program in Turkey will be beneficial for the competitiveness of agricultural enterprises and the improvement of working and living conditions in rural areas. It is vital that the IPARD program, which provides opportunities for solving rural development problems, is expanded throughout the country and that the funds allocated are used efficiently. The developments provided with IPARD supports will play an essential role in decoupling the differences in development between regions and sectors and leading to EU membership (Bedel, 2019).

The Agriculture and Rural Development Support Institution (ARDSI) is responsible for implementing the IPARD Program. As of 30 August 2011, ARDSI completed the accreditation and authorization transfer process carried out by the European Union Commission and started to provide IPARD supports. The second period of the Program (IPARD II), which covered the budget period 2014-2020 and whose last Call was made in 2021, has been continued by making several changes under the same primary goals mentioned above as in the previous Program. Bursa, one of the provinces where the Program was implemented, has been selected as a research area. One of the main factors in choosing Bursa province is the high potential of agricultural production, especially processing primary agricultural products such as milk, meat, fruits and vegetables, concerning the sectors included in the IPARD Program. The variety of local products such as olives, olive oil, Kemalpaşa dessert, Gedelek pickle, Iznik tiles and the availability of both sea and mountain rural tourism opportunities have also been other influential factors (Ozkan \& Kadagan, 2019).
There are few studies in the literature on the benefits of IPARD Projects to companies, their satisfaction and project outcome. Gülçubuk et al. (2018) and Olgun and Sevilmiş (2017) examined the effects of rural development support at the national level. Toker and Karlı (2021) tested the effects of the IPARD Program on the fruit growing sector in Isparta province. Koç and Giray (2016) investigated dairy cattle enterprises thoughts about IPARD project support in Yozgat and Sivas provinces. Beşen et al. (2020) in Antalya province, Aydın et al. (2019) in Edirne province examined the factors affecting producers drip irrigation support.

Factors affecting the utilization of investors from rural development projects, aspects that are disrupted in the implementation of projects and manufacturers' satisfaction levels have been studied in the Karaman (Demirbük \& Ayyıldız, 2021), Isparta (Özkul \& Bozkurt, 2020), Afyonkarahisar (Yardimci, Ari, \& Aslan, 2018), Denizli (Akın, 2016), Çanakkale (Tan et al. 2018), Konya (Örs \& Oğuz, 2019) and Mardin (Aslan, Demirhan, \& Ertaş, 2016) (Cihangir, Bilgiç, \& Aba, 2015), as well as in the Gulf of Edremit (Zengin \& Savgin, 2016) and the Western Mediterranean Region (Taşcıoğlu \& Sayın, 2017).

The only research available for Bursa province was conducted by Çobanoğlu et al. (2017). The authors evaluated the impact of the "Supporting Machinery and Equipment Purchases (SMEP)" subprogram within the scope of the Rural Development Investment Support Program, identified problems and presented solution suggestions. Manufacturers who received and did not receive support from the SMEP subprogram were compared based on various parameters.

The scope of the current research has been kept more comprehensive. Measures 101, 103 amd 302 in the IPARD I and IPARD II programs were included in the study with all their subcategories. The primary purpose of this research is to create a general framework for businesses that have received support in Bursa province, one of the 42 provinces where the IPARD I and IPARD II program has been implemented. For this purpose, we investigated the demographic characteristics of the business managers interviewed within the scope of the project and the investment and sector characteristics of the enterprises.

The current research will guide potential investors, local managers responsible for rural development and policymakers in relevant ministries.

\section{Material and Method}

\subsection{Population and Sample}

According to 2018 Turkish Statistical Institute (TUIK) data, the population of Bursa was 2994521 people (Turkstat, 2018a). The total agricultural area, excluding meadows and pastures, was 3040038 decares (Turkstat, 2018b). Bursa province received accreditation in the second phase period among 42 provinces where the IPARD Program was implemented. 185.99 million TL investment was made in Bursa, where 81.47 million TL grant support was provided to 213 projects in total, based on the years 2012-2016. Bursa is in 13th place among 42 provinces in terms of the number of grants paid. As of May 2019, 253 projects were carried out, and 88.3 million TL support was paid to these projects. 
IPARD I and IPARD II Programs for Bursa were taken together, and 247 projects were included in the sample. In order to determine the study sample, a homogeneous purposeful sampling method was used. Purposive sampling is a sampling method in which there is no probability effect. It allows for a more detailed examination by selecting vital areas as data. This method is preferred when working with notable cases with specific criteria or certain qualifications. The purpose of homogeneous sampling is to conduct an in-depth analysis by selecting a small and similar sample (Başaran, 2017).

Within the scope of the IPARD I Program in Bursa, a total of 73 projects and local products supported by 101 and 103 Measures and 16 projects that received support from 302 Measures, rural tourism sub-measures were included in the scope of the study. In addition, a total of 8 projects have been selected that have received support from the relevant sectors from the IPARD II Program and whose payment has ended. Due to the small population, a complete count method was applied. Accordingly, the total sample volume was determined to be 97 .

There were 22 questions in the questionnaire about the demographic characteristics of the participating individuals and companies and general information about the project. The survey was conducted face-to-face for 97 projects included in the sampling between January 2018 and February 2019. Most of the questions in the survey required single-choice answers. Only for 'the future investment plans of the project owners,' participants could select multiple options).

\subsection{Data Analysis}

We used the SPSS package program version 25 to analyze the participants' data, performed reliability analysis and normality test, and created cross tables. The Cronbach's alpha value of the scale was 0.902 . Cronbach's Alpha being $(\alpha) \geq 0.90$ confirms that the survey is "highly reliable". We also performed a Shapiro-Wilk test to test the normality assumption. The analysis showed that $(\mathrm{D}(97) \mathrm{p}=0.877, \mathrm{p}>0.05)$; the data did not show a normal distribution. Therefore, we used curvature and kurtosis values. We found the skewness values of $-0.040(\mathrm{SE}=0.148)$ and the kurtosis values of $-0.173(\mathrm{SE}=0.342)$. Tabachnick and Fidell (2013) stated that the skewness and kurtosis values of +1.5 and -1.5 met the normality assumption, so we accepted that the data were distributed normally.

\section{Results and Discussion}

\subsection{Demographic Characteristics of the Participants}

We examined the demographic characteristics of the participants of the supported enterprises and the general characteristics of the projects in Bursa. The demographic characteristics are shown in Table 1.

In the IPARD I Program, the priority of the female applicant in the ranking criteria was insufficient. This setback has been compensated in the IPARD II Program, and priority was given to women's applications. Since this research mainly covered companies participating in the first budget period program, this setback is apparent in the demographic data, and a large percentage of investors are men. We expect an increase in the number of women entrepreneurs in the second budget period (IPARD II) with the rise in the number of projects and additional points to be given to female applicants. There are 21 females $(21.6 \%)$ and $76(78.4 \%)$ male project owners in 97 projects. It is believed that the male project owner ratio is high for the reasons mentioned above. This result is similar to the studies conducted by Türkan and Değirmenci (2017), Çimen (2017) and Koç (2016).

The number of projects in the age groups in Table 1 shows that $52.7 \%$ of the project owners are 45 and younger. One of the factors determining the grant rate according to the IPARD program was the applicant's age. Being under 40 in the 101 measure increased the grant rate by 5\%; in the 302 Measure, the ranking score increased by $5-15$ points. The age criterion considers the applicant's age in natural persons and the person authorized to represent in legal entities. Of the projects covered by the study, $61.9 \%$ of the Measures were from Measure 101, $18.5 \%$ were from Measure 302. Measure 101 and 302 made up $80.4 \%$ in total. Despite this, the percentage of young farmers is low compared to expectations. The distribution of age groups is generally balanced show similarities with the studies conducted by Tan et al. (2018), Çimen (2017), Asoğlu and Binici (2015) and Koç (2016). In contrast, a study by Türkan and Değirmenci (2017) showed that the age groups of KOSGEB support beneficiaries were relatively younger. The application criteria between the programs may cause this difference.

In terms of marital status, there are 88 married $(90.7 \%)$ project owners but only nine single $(9.3 \%)$ project owners. Tan et al. (2018) reached similar findings in a study on manufacturers who received machine equipment support within the framework of the IPARD Program in Çanakkale province.

Educational status shows that more than $65 \%$ of the project beneficiaries are high school, associate and undergraduate graduates.

Since the projects within the scope of the study are predominantly from 101 Measures, we expected that the legal status of the project applicants would be natural persons at a high rate. However, in terms of the legal status of the project owners, it is approximately in half.

Table 1. Demographic characteristics of the participants

\begin{tabular}{llrrr}
\hline & & N & \% & Cumulative \\
\%ender & Female & 21 & 21.6 & 21.6 \\
& Male & 76 & 78.4 & 100.0 \\
Marital & Married & 88 & 90.7 & 90.7 \\
status & Single & 9 & 9.3 & 100.0 \\
Age & $\leq 25$ & 2 & 2.1 & 2.1 \\
& 26-35 & 18 & 18.6 & 20.7 \\
& $36-45$ & 31 & 32.0 & 52.7 \\
& $46-55$ & 35 & 36.1 & 88.8 \\
& 56 & 11 & 11.3 & 100.0 \\
& Primary Scool & 12 & 12.4 & 12.4 \\
Education & Secondary & 19 & 19.6 & 32.0 \\
& School & 24 & 24.7 & 56.7 \\
& High School & 40 & 41.2 & 97.9 \\
& Undergraduate & 4 & 2.1 & 100.0 \\
\hline & Graduate & 97 & 100.0 & \\
\hline
\end{tabular}

These findings align with the studies conducted by Gülçubuk et al. (2018) and Koç (2016). In the study of Türkan and Değirmenci (2017), the ratio of natural persons was higher, on the 
contrary, in another study conducted by Çimen (2017) and Özdemir (2014), the proportions of legal entities were higher. According to the application criteria in the region, province and given supports, the legal and natural person ratios may vary.

\subsection{Applicant and Project Characteristics}

\subsubsection{Types of Businesses Involved in the Project and Supported Sectors}

The distribution of the projects covered by the study by the enterprise type showed that 82 new (84.5\%) and 15 existing business $(15.5 \%)$ applications benefitted from IPARD Projects (Table 2). These findings are supported by the studies conducted by Çimen (2017) and Koç (2016). In contrast, a study conducted by Taşcioğlu and Sayın (2017) found that the proportion of existing businesses was higher. This difference may occur due to the application criteria given priority in the support program.

Applying as an existing business in the IPARD ranking criteria has started to provide an advantage to applicants from the second phase of the Program. In the IPARD II, 1. and 5. Calls of the 101 Measure, 20 points were granted to the existing enterprises in the ranking criteria. For the 103 Measure, 40 points were granted to the existing enterprises during the 1. 2. and 5. Calls. However, in the IPARD I period, no ranking advantage was provided for the existing business applications.

Additionally, some sub-sectors, existing enterprises and capacity-building enterprises have not received support during the IPARD II budget period. For example, there was no support given to new and existing enterprises in the poultry meat production sector that increased their capacity in Bursa. In addition, new businesses and capacity increase were not supported in red meat and poultry meat processing and poultry meat shredding projects. Since most of the projects covered by the study are IPARD I period projects, $84.5 \%$ of the projects supported were new businesses. Accordingly, in the IPARD I budget period, especially existing enterprises engaged in primary agricultural production and process agricultural products in Bursa province have not benefited enough from these projects to reach community standards. We anticipate that there will be an increase in the ratio of existing enterprises supported during the IPARD II period.

Examination of the data obtained in the study shows that meat and milk producing enterprises are dominant in terms of the supported sectors. The number of projects in milk processing, meat processing and fruit and vegetables, which require relatively high investment costs, is at lower levels. Although the budget differences between the measures in the IPARD Program were not very large, the differences in the investment budgets per Call may cause these differences. Likewise, the higher grant rates allocated to investments in dairy and meat producing enterprises in Measure 101 may have increased the demand for these sectors.

There was no vast difference in the allocation of the budgets in the IPARD Program between the measures. On the other hand, the allocated budgets per project differed when we compared the measures, particularly the 101 and 103 Measures. The maximum eligible expenditures were $€ 1$ million in Measure 101 and $€ 3$ million in Measure 103. Therefore, the number of projects in the 101 Measure, which had lower investment costs, should be higher. The number of projects in milk processing, meat processing and fruit and vegetables, which require relatively high investment costs, is at lower levels. Further, the higher grant rates in the 101 Measure may increase the demand for investments in dairy and meat producing enterprises. As a result, we can say that in the distribution of the sectors supported within the scope of the research, the enterprises that produce meat and milk, that is, the projects belonging to the 101 Measure, are predominant.

Table 2. Types of businesses involved in the project and supported sectors.

\begin{tabular}{|c|c|c|c|}
\hline & & $\mathbf{N}$ & $\%$ \\
\hline Enterprise & New & 82 & 84.5 \\
\hline Type & Existing & 15 & 15.5 \\
\hline Business & Normal Person & 47 & 48,5 \\
\hline Entity & Legal Person & 50 & 51,5 \\
\hline \multirow{8}{*}{$\begin{array}{l}\text { Supported } \\
\text { Sectors }\end{array}$} & $\begin{array}{l}\text { Milk Producing Agricultural } \\
\text { Holdings }\end{array}$ & 25 & 25.8 \\
\hline & $\begin{array}{l}\text { Red Meat Producing Agricultural } \\
\text { Holdings }\end{array}$ & 35 & 36.1 \\
\hline & $\begin{array}{l}\text { Processing and Marketing of Milk } \\
\text { and Milk Products }\end{array}$ & 2 & 2.1 \\
\hline & $\begin{array}{l}\text { Processing and Marketing of Red } \\
\text { Meat and Meat Products }\end{array}$ & 5 & 5.2 \\
\hline & $\begin{array}{l}\text { Processing and Marketing of Fruits } \\
\text { and Vegetables }\end{array}$ & 12 & 12.4 \\
\hline & $\begin{array}{l}\text { Crafts and Artisanal Added Value } \\
\text { Product Enterprises }\end{array}$ & 11 & 11.3 \\
\hline & $\begin{array}{l}\text { Rural Tourism and Recreational } \\
\text { Activities }\end{array}$ & 7 & 7.2 \\
\hline & Total & 97 & 100 \\
\hline
\end{tabular}

\subsubsection{Capacities and Locations of Supported Enterprises}

We examined the enterprises' installed capacities after receiving the grant support after completing the project application and becoming operational. These capacities are categorized into low, medium, and high capacity groups. When grouping, we took the means values of the minimum and maximum rates of the IPARD Program-specific eligibility criteria. Accordingly, $6.2 \%$ of the research subject projects are low-capacity, $21.6 \%$ medium and $72.2 \%$ high capacity (Table 3 ).

The results show that enterprises with high installed capacity make a significant part of the IPARD project applications. These findings are similar to the studies conducted by Çimen (2017) and Koç (2016).

There were sector-specific capacity criteria in the IPARD Program. It has been aimed to increase the number of projects with lower capacity and budget, especially from the 14th Call of the IPARD I budget period and onwards. Thus, it would enable more investors to benefit from the allocated budget, and support would be extended to the sector base following the general objectives of the IPARD Program. For this purpose, arrangements have been made to allocate additional points to low-capacity projects in the ranking criteria in the IPARD I budget period, 14th Call for the 101 Measure. IPARD II budget period further expanded this allocation. From the 14th Call of the IPARD II budget period, criteria for budget and installed capacity was established for Measures 101 and 103. Priority was given to lowbudget and low capacity projects. 
Table 3. The capacities of the supported enterprises and their distance from the centre

\begin{tabular}{llrr}
\hline & & $\mathbf{N}$ & \% \\
\hline Installed Capacity & Low & 6 & 6.2 \\
& Medium & 21 & 21.6 \\
& High & 70 & 72.2 \\
\hline Have you made a & Yes & 7 & 7.2 \\
capacity increase? & No & 90 & 92.8 \\
\hline Distance to the & In the Provincial Centre & 2 & 2.1 \\
Provincial Centre & $\leq 25 \mathrm{~km}$ & 9 & 9.3 \\
& $25-50 \mathrm{~km}$ & 13 & 13.4 \\
& $50-75 \mathrm{~km}$ & 36 & 37.1 \\
& $75 \mathrm{~km} \leq$ & 37 & 38.1 \\
\hline Distance to the & In the District Centre & 8 & 8.2 \\
District Centre & $\leq 10 \mathrm{~km}$ & 25 & 25.8 \\
& $10-20 \mathrm{~km}$ & 32 & 33.0 \\
& $20-30 \mathrm{~km}$ & 21 & 21.6 \\
& $30 \mathrm{~km} \leq$ & 11 & 11.3 \\
\hline Do you live in the & Yes & 61 & 62.9 \\
same county as & No & 36 & 37.1 \\
your business? & & & \\
\hline
\end{tabular}

Accordingly, a significant part of the projects consists of enterprises operating at high installed capacity within the limits of the IPARD Program. Investors seem to prefer investments with the highest possible capacity, as it is a more efficient and grantsupported investment opportunity as far as their financial means allow. Thus, especially in the IPARD 1 budget period, highcapacity projects were supported, and fewer investors could benefit from the allocated budget.

Already the data on monthly agricultural net income also confirm this situation. The ARDSI, the Institution that implements the support program, noticed this problem, have taken corrective action. After that, it will be likely that projects with lower capacity and budgets will come to the fore within the Program to be implemented.

We questioned whether there were capacity increases after receiving grant support and found no capacity increase at a very high rate of $92.8 \%$. It is not easy to find sufficient financing for additional investments such as capacity increase after the project has consequently become operational. This rate has been relatively high. Although Koç (2016) gave a lower rate in his study, he made similar comments to these observations mentioned.

Another factor that affects the grant rates of projects that would receive support from the IPARD Program was whether the investment land was located in a mountainous area. "Mountainous Area" is defined as an area located at a minimum altitude of 1000 meters or at an altitude between 500 and 1000 meters and having a minimum slope of $17 \%$ (IPARD Programme). Villages and neighbourhoods that meet the mentioned mountainous area criteria are constantly updated and published on the official websites of ARDSI and the Ministry of Agriculture and Forestry. In projects that meet the mountainous area criterion in 101 Measure, a grant rate increase of $10 \%$ is provided in the IPARD I program and 5\% in the IPARD II program. Further, the investments made in mountainous areas in the projects in the 302 Measure gain additional points in the ranking criteria. Due to low altitude, the province and many district centres of Bursa are not considered mountainous.
Resultingly, the projects within the scope of the study are concentrated in areas far from these centres.

Of the institutions involved in the project, $75.2 \%$ are located more than $50 \mathrm{~km}$ from the provincial centre, and $65.9 \%$ are located more than $10 \mathrm{~km}$ from the district centre (Table 3).

Similarly, in the Tan et al. (2018) research, investors reside within the borders of the same district.

\subsubsection{Sectoral Experiences and Educational Qualifications of the Participants}

The professional experience of the project owners of the study is shown in Table 4 . The highest rate is $40.2 \%$ for those with 1-5 years of professional experience. The fact that entrepreneurs who have just entered the profession apply to these programs and get involved in the project shows that new entrepreneurs are more open to taking risks and developing than experienced entrepreneurs. New entrepreneurs follow the relevant projects, do not get tired of the necessary paperwork and application procedures. At the same time, entrepreneurs who have gained experience in other fields may want to expand their businesses towards these areas with the help of IPARD grants.

In addition, the survey participants were asked whether they had formal education (high school or university) related to the sector in which their businesses operate, and $83.5 \%$ of them stated that they had no education. Further, the project owners were asked whether they had received vocational training or courses related to the sector in which their businesses operate. Again, the vast majority (76.3\%) declared that they did not take a course. The findings prove that the IPARD Program has failed to reach an investor's target with sufficient and relevant education for the relevant sectors in Bursa.

There is a professional qualification requirement among the general eligibility criteria for the IPARD Program 101 Measure. This condition has also been applied for Measures 103 and 302 until the 12th call period of the IPARD I Program. To comply with the professional qualification requirement of the Program, the applicant (if the applicant is a natural person by the applicant if the applicant is a legal entity by the authorized representative) must have an agricultural vocational high school, vocational school or university diploma (including master or doctorate). Alternatively, prove their competence with a minimum of three years of work experience in agriculture or other related specialities, which the relevant national registration systems can document. Individuals considering investing may be inclined to apply to provide this professional qualification criterion as a legal entity. In addition, in the criteria for ranking the 302 Measures for the IPARD II budget period, an additional 15 points are given if the applicant has a professional certificate, diploma or three years of experience in economic activity. For these reasons, the rate of natural person applications has been realized in half, less than the expectations. In addition, since one of the options to meet the vocational qualification requirement was a diploma, project owners were expected to have diplomas from the relevant professional branches to a significant extent. However, only $16.5 \%$ of the investors have formal education related to the sector, and $23.7 \%$ have vocational training or course certificates.

The findings on professional education are similar to the study conducted by Özdemir (2014). Contrarily, the professional experience periods of the business owners who have received support, whether they have received a professional certificate or 
a course, differ in the current research. (Tan et al. 2018; Çimen, 2017; Özdemir, 2014; Akın, 2016; Taşcığlu \& Sayın, 2017; Koç 2016). These differences may result from the different scope of the support program, application requirements, supported regions and sectors.

Table 4. Sectoral experiences and educational qualifications of the participants

\begin{tabular}{llrrr}
\hline & & N & \% & Cum. \% \\
\hline & $1-5$ & 39 & 40.2 & 40.2 \\
Professional Experience & $5-10$ & 17 & 17.5 & 57.7 \\
(Years) & $10-15$ & 16 & 16.5 & 74.2 \\
& $15-20$ & 11 & 11.3 & 85.6 \\
Do you have formal & $20+$ & 14 & 14.4 & 100.0 \\
education related to the & Yes & 16 & 16.5 & 16.5 \\
$\begin{array}{llll}\text { sector? } \\
\text { Have you attended a }\end{array}$ & No & 81 & 83.5 & 100.0 \\
$\begin{array}{l}\text { vocational education or a } \\
\text { course? }\end{array}$ & No & 23 & 23.7 & 23.7 \\
& & 74 & 76.3 & 100.0 \\
\hline
\end{tabular}

\subsubsection{Income Status of the Participants}

In $71.1 \%$ of the supported enterprises, the top manager is the project owner, in $18.6 \%$, it is a family member of the project owner, and in the remaining $10.3 \%$, it is one of the other third parties (Table 5). The current findings related to the enterprise's top management are in line with the findings of Kandemir, Baykut and Avc1 (2017) and Çimen (2017).

We asked the project owners if they had non-agricultural income. Table 5 shows that $59.8 \%$ of the project owners have no income from non-agricultural activities. In other words, only $40 \%$ of the project owners make a living only through agricultural activities. Further, a significant majority of those with nonagricultural income also have a monthly net income of TL 10,000 and below.

Table 5. Income status of the participants

\begin{tabular}{llrrr}
\hline & & $\mathrm{N}$ & $\%$ & Cum \% \\
\hline & Myself & 69 & 71.1 & 71.1 \\
$\begin{array}{l}\text { Who is the head of } \\
\text { the business? }\end{array}$ & $\begin{array}{l}\text { Someone From a } \\
\text { Family }\end{array}$ & 18 & 18.6 & 89.7 \\
Other & 10 & 10.3 & 100.0 \\
$\begin{array}{l}\text { Do you have non- } \\
\text { agricultural }\end{array}$ & Yes & 39 & 40.2 & 40.2 \\
income? & No & 58 & 59.8 & 100.0 \\
& & & & \\
Monthly Non- & 55000 & 15 & 15.5 & 75.3 \\
Farm Net Income & $10001-15000$ & 11 & 11.3 & 86.6 \\
(TL) & $15001-20000$ & 5 & 3.1 & 89.6 \\
& $20001 \leq$ & 5 & 5.2 & 94.8 \\
Monthly & $\leq 5000$ & 5 & 5.2 & 100.0 \\
Agricultural Net & $5001-10000$ & 19 & 19.6 & 24.7 \\
Income & $10001-15000$ & 23 & 23.7 & 48.5 \\
& $15001-20000$ & 19 & 19.6 & 68.0 \\
& $20001 \leq$ & 31 & 32.0 & 100.0 \\
& & & & \\
\hline
\end{tabular}

Findings regarding non-agricultural income may vary according to the sectors region and amount of the grant. For example, $61.3 \%$ of the producers receiving drip irrigation support in Antalya have an income other than agriculture (Beşen et al., 2020), $82.93 \%$ of those benefiting from drip irrigation support in Edirne have non-agricultural income (Aydin et al. 2019). On the other hand, $36 \%$ of the enterprises that received machine equipment support in Çanakkale had non-agricultural income (Tan et al., 2018). Further, $47.1 \%$ of dairy enterprises that benefited from IPARD Projects in Afyonkarahisar had nonagricultural income (Yardimci, Ari, \& Aslan, 2018).

The monthly agricultural net income status of the enterprises supported under the IPARD Program was investigated. The results given in Table 4 show that the highest rate $(32.0 \%)$ in the monthly agricultural net income data is in the highest income group, and the lowest rate $(5.2 \%)$ is in the lowest income group. $72.2 \%$ of the enterprises receiving support within the scope of the study have a high installed capacity. The fact that $72.2 \%$ of the enterprises receiving support have high capacity according to IPARD specific eligibility criteria as installed capacity leads to this monthly distribution of net agricultural income.

\subsubsection{Monthly Net Income Distribution based on Sectors}

Table 6 shows the distribution of the monthly net income of the businesses receiving support based on the sectors in which they operate. The companies with revenues of TL 15,000 and below mainly belong to the dairy and meat producing sectors in Measure 101. Higher investment costs necessary for milk processing, meat processing, fruit and vegetable processing enterprises mainly in 103 Measure were expected to have a higher monthly income. The research results reflected this expectation.

\subsubsection{Information Resources of the Participants}

Regarding ARDSI grant support, $58.8 \%$ of the investors who participated in the survey received information from ARDSI introductory meetings, and 30.9\% from investors who had previously received grant support. The remaining few investors also received information from the Provincial or District Agricultural Directorates, the institutional website, newspaper advertisements and brochures (Table 7).

ARDSI publicity meetings and investors who had previously received support have effectively informed about IPARD Program grants in Bursa. Here, it is seen that ARDSI has carried out an effective promotional meeting process in Bursa and that the projects that have been carried out by receiving grant support and are in operation are pretty effective in guiding and encouraging new investors.

In many studies (Tan et al. 2018), Iovaand Cretu, 2017; Kadiroğlu \& Türko, 2018; Akın, 2016; Koç, 2016), the distribution of news sources of grant support varies widely. The difference may occur due to many parameters like the process management of the Institution responsible for the management of support, the content of the support program, the region and sectors supported. The majority of the project owners (89.7\%) stated that they follow the rural development activities in Turkey. This result is similar to the study conducted by Akın (2016). 
European Journal of Science and Technology

Table 6. Monthly net income distribution of enterprises based on sectors

\begin{tabular}{cccccccc}
\hline No & Sectors & $\mathbf{5 0 0 0}$ & $\mathbf{5 0 0 1 - 1 0 ~ 0 0 0}$ & $\mathbf{1 0 0 0 1 - 1 5 0 0 0}$ & $\mathbf{1 5 0 0 1 - 2 0 ~ 0 0 0}$ & $\mathbf{2 0 0 0 1} \leq$ & Total \\
\hline 1 & Milk Producers & 1 & 13 & 3 & 3 & 5 & 25 \\
2 & Red Meat Producers & 3 & 3 & 16 & 7 & 6 & 35 \\
3 & Milk and Milk Prod. Processors & 0 & 0 & 0 & 1 & 1 & 2 \\
4 & Red Meat and Meat Prod Processors & 0 & 0 & 0 & 0 & 5 & 5 \\
5 & Fruits and Vegetables & 0 & 0 & 1 & 5 & 6 & 12 \\
6 & Crafts and Artisanal Product & 0 & 1 & 2 & 2 & 6 & 11 \\
7 & Rural Tourism & 1 & 2 & 1 & 1 & 2 & 7 \\
\hline & Total & 5 & 19 & 23 & 19 & 31 & 97 \\
\hline
\end{tabular}

Table 7. Information resources of the participants

\begin{tabular}{|c|c|c|c|}
\hline & & $\mathbf{N}$ & $\%$ \\
\hline \multirow{4}{*}{$\begin{array}{l}\text { Where did you get information about } \\
\text { grant supports? }\end{array}$} & ARDSI Promotional Meetings & 57 & 58.8 \\
\hline & Newspapers, advertisements, brochures & 1 & 1.0 \\
\hline & The Institutional Website & 4 & 4.1 \\
\hline & Provincial or District Agricultural Directorates & 5 & 5.2 \\
\hline \multirow{2}{*}{$\begin{array}{l}\text { Do you follow the rural development } \\
\text { activities? }\end{array}$} & Yes & 87 & 89.7 \\
\hline & No & 10 & 10.3 \\
\hline
\end{tabular}

\subsubsection{Future Investment Plans of Enterprises}

The project owners participating in the study were asked about their future investment plans for their businesses, and it was stated that they could mark multiple options. The results obtained are given in Table 9 through Table 9.

The previous section (Table 3 ) stated that investors mostly applied for large-scale IPARD Projects, and almost all of the investors did not increase capacity within the project. The findings obtained from this section confirm this previous finding. We see that (Table 8) investors mainly apply to projects to maintain their current operations. Since investors are already applying for these projects using their maximum financial means, they are deciding to maintain their current business situation in the future. Another equivalent response is that investors are considering investing in additional machine equipment without increasing capacity. Accordingly, the idea

\subsubsection{Distribution of Future Investment Plans of Enterprises by Sectors}

Table 8 shows the plans of investors receiving IPARD support by sectors. Among the agricultural enterprises producing milk, $68 \%$ want to "continue their activities while maintaining the current situation", while $60 \%$ want to "Invest in additional machinery and equipment without increasing the capacity". Only $44 \%$ of the investors in this sector want to increase their business capacity. In meat-producing agricultural enterprises, $57.1 \%$ wanted to "continue their activities while maintaining their current status", while $51.4 \%$ chose to "increase capacity". While half of the milk processing companies want to maintain their current status, half want to invest in additional machinery and equipment without increasing capacity. It is alarming that half of the milk processing companies want to invest in a different sector in a different address.

All of the enterprises operating in the red meat and meat processing sector want to invest in additional machinery and of preserving the current situation of investors and making only needed machinery and equipment investments came to the fore at the first stage. The desire not to make additional investments due to financing difficulties in the initial stages of the new postinvestment operating period is understandable (Gurbuz \& Ozkan, 2019).

During these periods, it should be taken into account the possibility that a significant part of the income of enterprises is used to cover financing expenses such as investment loans. However, the number of investors who plan to increase capacity is also 46. Accordingly, investors want to increase their capacity to the extent that the IPARD capacity limits are insufficient, and the current financing situation is significantly higher.

equipment without increasing the capacity. $80 \%$ of them want to improve production without increasing capacity. The sector most willing to increase capacity is the fruit and vegetable sector, where $83.3 \%$ of investors want to increase their operating capacity in the future. The upper limit of IPARD capacity in the vegetable sector is $10,000 \mathrm{~m}^{3}$, and the volume of work is above the current capacity of most of the companies in the sector. The upper limit of IPARD capacity in the vegetable sector is $10,000 \mathrm{~m} 3$, and the volume of work is above the current capacity of most of the companies in the sector.

Local craftsmen and artisans primarily aim to maintain the current state and invest in additional machinery and equipment without increasing capacity (Gurbuz, Erol, \& Yavuz, 2002). Most enterprises want to invest in equipment and services in the rural tourism sector without increasing capacity. All in all, in sectors with relatively higher monthly net incomes, enterprises plan capacity growth at a more significant percentage in their investment plans. In comparison, those with relatively lower incomes tend to maintain the current situation. 
Table 8. Distribution of future investment plans of enterprises by sectors

\begin{tabular}{|c|c|c|c|c|c|c|c|c|c|}
\hline \multirow[b]{2}{*}{ What are your future plans? } & \multicolumn{9}{|c|}{ Sectors* } \\
\hline & 1 & 2 & 3 & 4 & 5 & 6 & 7 & Total & $\%$ \\
\hline To increase the business capacity & 11 & 18 & 0 & 1 & 10 & 3 & 3 & 46 & 21.1 \\
\hline To invest in additional machine equipment without increasing capacity. & 15 & 16 & 1 & 5 & 6 & 8 & 5 & 56 & 25.7 \\
\hline To improve production without increasing capacity. & 8 & 4 & 0 & 4 & 3 & 3 & 5 & 27 & 12.4 \\
\hline Setting up a business in the same sector at a different address. & 4 & 2 & 0 & 2 & 2 & 0 & 1 & 11 & 5.0 \\
\hline Setting up a business in a different sector at a different address. & 5 & 11 & 1 & 0 & 2 & 1 & 2 & 22 & 10.1 \\
\hline Maintaining the current state of the enterprise and continuing activities as usual. & 17 & 20 & 1 & 2 & 3 & 9 & 4 & 56 & 25.7 \\
\hline Total & 25 & 35 & 2 & 5 & 12 & 11 & 7 & 218 & 100.0 \\
\hline
\end{tabular}

*The numbers that sectors stand for are given in Table 6 .

\subsubsection{Distribution of Future Investment Plans of Enterprises by Net Income per Month}

The results of monthly net revenues (Table 9) show that, as predicted, enterprises with monthly net income of TL 15 thousand and above mostly plan to increase business capacity.

Maintaining the enterprise's current state and continuing activities and investing in additional machinery and equipment without increasing capacity are included in the plans of all enterprises regardless of the profit made almost at an equal rate.

It is common in all sectors for enterprises with relatively higher incomes to plan to increase future capacity. However, the primary purpose of the IPARD Projects was to ensure rural development. Rural development will be achieved by expanding the industry, creating new enterprises of all sizes, investing in technology that improves the quality and range of products offered and increasing production capacity in large companies and small businesses. However, in the current situation, the plans of small and medium-sized manufacturers who benefit from IPARD Projects are more conservative. These projects primarily provide large-scale investors with the opportunity to make a growth plan for the future. Of course, during the current project periods, how investors perceive the economic situation in the country and the agricultural and trade policies implemented can also affect their business plans.

Table 9. Distribution of future investment plans of enterprises by net income per month

\begin{tabular}{|c|c|c|c|c|c|c|}
\hline & \multicolumn{6}{|c|}{ Monthly Agricultural Net Income } \\
\hline & $\leq 5000$ & $\begin{array}{c}5001-10 \\
000\end{array}$ & $\begin{array}{l}10001- \\
15000\end{array}$ & $\begin{array}{l}15001- \\
20000\end{array}$ & $20001 \leq$ & Total \\
\hline To increase the capacity of the business. & 1 & 8 & 9 & 12 & 16 & 46 \\
\hline To improve production without increasing capacity. & 1 & 7 & 4 & 3 & 12 & 27 \\
\hline $\begin{array}{l}\text { Setting up a business in a different sector at a different } \\
\text { address and investing in it. }\end{array}$ & 0 & 3 & 7 & 6 & 6 & 22 \\
\hline $\begin{array}{l}\text { Maintaining the current state of the enterprise and } \\
\text { continuing activities as usual. }\end{array}$ & 3 & 12 & 14 & 11 & 16 & 56 \\
\hline Total & 5 & 19 & 23 & 19 & 31 & 97 \\
\hline
\end{tabular}

\section{Conclusions and Recommendations}

The EU has collected financial aid for a candidate and potential candidate countries under one roof under the name of the Pre-Accession Assistance Instrument (IPA). The main goal of these financial aids is to support projects that serve the needs and priorities of candidate countries towards becoming members of the community and facilitate compliance with the EU acquis through these projects and create the administrative capacity necessary for this compliance. The IPARD II Program is currently being implemented in 42 provinces in Turkey.

The results revealed that most of the project owners supported in Bursa live in the same district where the investment was made. They have no income outside the agricultural activity, follow the rural development activities, own the enterprises, manage and apply to the grant. These findings show that the beneficiaries of the IPARD Program can reach the intended target audience of the Program in Bursa. However, the Program has not reached the female investors and young entrepreneurs who are given priority. However, a significant proportion of project owners have relatively high educational levels. At this point, the addition of age criteria to the priority ranking criteria of the Program will further encourage young investors.

Most of the projects have high capacity and income within limits set by the IPARD Program. Nevertheless, new investment plans such as capacity growth are less than the expected level 
due to financial sustainability concerns of the applicants.

The Program failed to reach the target investors with the desired education and training relevant to the supported sector in Bursa province, where there were predominantly 101 measures. How the investor perceives the impact of the support program is a rather complicated situation. In summary, from the enterprises that have received support in Bursa province, the legal entities with high monthly net income and the highly educated project owner have benefited more.

We recommend that investors be more informed about the main goals and objectives of the IPARD Program in natural person enterprises, enterprises with low monthly net incomes and beneficiaries with low educational levels, particularly for Bursa province.

\section{References}

Akın, O. (2016). Rural development potential of Denizli province in respect to Instrument for Pre-accession Assistance Rural Development Programme (IPARD) of the EU. Pamukkale University Journal of Social Sciences Institute, 25(1), 340-356.

Aslan, S., Demirhan, Y., \& Ertaş, M. (2016). EU pre-accession assistance for rural development component (IPARD I) and the effect to the province of Mardin. Journal of Academic Approaches, 7(1), 232-254.

Asoğlu, V., \& Binici, T. (2015). Evaluation of economic investments of RDISPs: Şanlıurfa and Diyarbakır example. Electronic Journal of Social Sciences, 14(52), 221-230. doi:10.17755/esosder.26433

Aydın, B., Öztürk, O., Çebi, Ü., Özkan, E., \& Özer, S. (2019). Factors affecting the utilization from drip irrigation subsidies of the farmers in Edirne province. Soil Water Journal, 8(2), 87-95.

Başaran, Y. K. (2017). Sampling theory in social sciences. Asos Journal the Journal of Academic Social Science, 5(47). doi:10.16992/ASOS.12368

Bedel, N.E. (2019). A field study on concept of rural development, quality and sustainability in the agricultural enterprises which supported by agriculture and rural development support institution (province of Bursa), Bursa Uludağ Üniversitesi (Unpublished Master Thesis). Bursa.

Beşen, T., Sayın, B., Çelikyurt, M. A., Kuzgun, M., Yılmaz, Ş. G., Bahçeci, M., \& Aydın, B. (2020). Determination of factors affecting the receiving drip irrigation support of producers in Antalya province. KSU Journal of Agriculture and Nature, 23(6), 1578-1586. doi:10.18016/ksutarimdoga.vi.652397

Cihangir, H., Bilgiç, B., \& Aba, T. (2015). The impact of IPARD machinery and equipment supports on Mardin's agriculture. Journal of Agricultural Machinery Science, 11(1), 25-31.

Çimen, A. O. (2017). A survey on the contributıons of IPARD Programme to the economy (Unpublished Master Thesis). Ankara University, Ankara.

Çobanoğlu, F., Tunalığlu, R., Yılmaz, H. İ., Bozkıran, S., Nalbantoğlu, A., \& Yıldız, H. (2017). Assessment of impact of rural development investments support programme: evidence from Bursa region. Journal of Tekirdag Agricultural Faculty, 14 (01), 16-27.
Demirbük, M., \& Ayyıldız, B. (2021). Evaluation of the factors affecting benefiting from the grant program in rural development projects, case study of sariveliler, Karaman province. Anadolu Journal of Agricultural Sciences, 36, 34-44.

Gülçubuk, B., Köksal, Ö., Ataseven, Y., Gül, U., \& Kan, M. (2018). Effects of rural development supports at the national level: Examing of Agriculture and Rural Development Support Institution (ARDSI)'s Projects. TEAD, 2,(1), 1-10.

Gurbuz, I., Erol, A. O., \& Yavuz, O. (2002). Dünya'da ve Türkiye'de kırsal turizm. Türkiye V. Tarım Ekonomisi Kongresi 18-20 Eylül 2002. Erzurum, Türkiye.

Gurbuz, I. B., \& Ozkan, G. (2019). What's going on at the universities? How much has the research revealed university students' attitudes towards the environment? a case study of Bursa, Turkey. Applied Ecology and Environmental Research, 17(2), 5109-5138. doi:10.15666/aeer/1702_51095138

Iova, A. R., \& Cretu, D. (2017). The impact of the European funds on the development of the rural area. Case study. Scientific Papers Series Management, Economic Engineering in Agriculture and Rural Development, 17(2), 87-192.

Kadiroğlu, A., \& Türko, E. S. (2018). Project process in companies that received grants from regional development agency financial support programmes: Nada case. Journal of Business Economics and Management Research(2), 4970.

Kandemir, T., Baykut, E., \& Avc1, A. (2017). An assessment of small and medium enterprises development organization (KOSGEB) incentives from the perspective of support receiving organizations (TR33 region implementation). Optimum Journal of Economics and Management Sciences, 4(1), 97-114. doi:10.17541/optimum.285228

Koç, A. (2016). IPARD in funding rural development in Turkey on the path towards EU (Unpublished $\mathrm{PhD}$ Thesis). Süleyman Demirel University, Isparta.

Koç, A., \& Giray, F. H. (2016). Dairy cattle enterpreneurs' opinion on IPARD project supports. 12. National Agricultural Economics Congress, 25-24 May 2016, Isparta (pp. 975-984).

Olgun, F. A., \& Sevilmiş, G. (2017). European Union Instrument for Pre-accession Assistance-rural Development (IPARD) programme and assessment in terms of Turkey. Turkish Journal of Agricultural Economics, 23 (1), 25-36. doi:10.24181/tarekoder.317836

Örs, A., \& Oğuz, C. (2019). Unit milk cost and profitability of dairy cattle farms supported and non-supported by IPARD program: a case study of Konya, Turkey. Custos E Agroengocio online, 15(4), 471-484. doi:10.81043/aperta. 75347

Özdemir, Ş. (2014). Evaluating the properties of beneficiaries as part of IPARD programme: A case study in Konya. (Unpublished Master Thesis). Selçuk University. Konya.

Ozkan, G., \& Kadagan, O. (2019). An evaluation for agricultural development of agricultural potential in Bursa. Turkish Studies-Economics, Finance, Politics, 14(2), 503522. doi:10.29228/TurkishStudies. 22850

Özkul, G., \& Bozkurt, A. A. (2020). The effect of ARDSI supports on regional development and firm growth performance: Isparta Sample. Gümüşhane University Journal of Social Sciences Institute, 11(3), 676-698. 
Tabachnick, B. G., \& Fidell, L. S. (2013). Using Multivariate Statistics. Pearson.

Tan, S., Ekinci, Ö., Kurt, H., \& Karakoç, N. (2018). Analysis of factors affecting the satisfaction level of producers from machinery-equipment support within the scope of the IPARD project in Çanakkale. COMU Journal of Agriculture Faculty, 6(1), 1-8.

Taşcioğlu, Y., \& Sayın, C. (2017). Determination of the factors affecting the use of the support program of the enterprises benefiting from the rural development investments program in the western Mediterranean region. Turkish Journal of Agriculture - Food Science And Technology, 5(7), 786-791. doi:10.24925/turjaf.v5i7.786-791.1190

Toker, A., \& Karl1, B. (2021). The effects of IPARD program on fruit sector: the case of Isparta province. Turkish Journal of Science and Engineering, 3(1), 13-21.

Turkstat. (2018). Bursa provincial coordinator, publication no: 21 February 2018. Bursa.

Turkstat. (2018b). Provincial populations by years publication no: 1590. Ankara.

Türkan, Y., \& Değirmenci, Ö. (2017). Support of KOSGEB, supports using the evaluation of business and the city of application Bingöl. Bingöl University Journal of Social Sciences Institute, 7, 159-175. doi:10.29029/busbed.365207

Yardimci, M., Ari, H., \& Aslan, R. (2018). The impact of IPARD supports on structural and managerial features of dairy enterprises in Afyonkarahisar province. Indian Journal of Animal Research, 52(1), 151-156.

Zengin, B., \& Savgın, E. C. (2016). Pre-accession EU rural development funds IPARD examination of rural tourism support. Academic Review, 57, 84-100. 